\title{
Two and a Half Hours of Cardiopulmonary Resuscitation in a Deceased Brain Dead Donor before Liver Transplantation - A Good Idea to Accept?
}

\section{Dieter P. Hoyer, Gernot M. Kaiser, Andreas Paul, Nikolaos Machairas, Ernesto P. Molmenti, Georgios C. Sotiropoulos}

Department of General, Visceral and Transplantation Surgery, University Hospital Essen, Germany

Corresponding author:

Dieter Paul Hoyer, MD

General, Visceral and Transplantation

Surgery, University Hospital Essen

Hufelandstr. 55, 45122 Essen, Germany

E-mail: dieter.hoyer@uk-essen.de

\author{
Rezumat \\ Două ore și jumătate de resuscitare cardio-pulmonară a unui pacient donator în \\ moarte cerebrală înaintea efectuării transplantului de ficat - o idee acceptabilă?
}

Sechelele stopului cardiac şi a resuscitării cu compresie toracică (RCP) a donatorilor de organe pot rezulta în leziuni ischemice ale organelor şi în disfuncții ale grefelor după transplant. Nu a fost încă stabilită o limită maximă a timpului de resuscitare a donatorilor aflați în moarte cerebrală. Prezentăm cazul unui donator de ficat aflat în moarte cerebrală care a fost supus RCP, a cărui ficat a fost transplantat cu succes. Un bărbat în vârstă de 75 de ani a fost tratat în urma unui stop cardiac prin RCP cu administrare de streptokinază timp de 2.5 ore, până la stabilizarea funcției cardiace. Moartea cerebrală a fost diagnosticată în ziua internării şi donarea de organe s-a desfăşurat în interval de 24 de ore. Indicele de risc al donatorului a fost de 2.2 cu timpul de ischemie rece de 8.8 ore. Ficatul a fost transplantat unui pacient de 64 de ani suferind de ciroză alcoolică, cu scor MELD 10, nereprezentativ pentru gravitatea bolii. În timpul perioadei de urmărire de 4 ani, au fost efectuate în mod regulat ERCP şi stentare pentru stenozele biliare pe anastomoză. Pacientul a rămas într-o stare generală foarte bună fără semne de disfuncție a ficatului. Acest caz demonstrează că o perioadă de timp mai îndelungată de RCP nu reprezintă obligatoriu un criteriu de excludere pentru donarea ficatului. Este nevoie de stabilirea unei limite de timp pentru RCP şi a factorilor predictibili în cazul donatorilor în stop cardiac.

Cuvinte cheie: riscul donatorului, transplant de ficat, ischemie / reperfuzie, precondiționarea ischemică, donatori marginali, luarea deciziei clinice

\begin{abstract}
The sequelae of cardiac arrest (CA) and cardiopulmonary resuscitation (CPR) in organ donors potentially results in ischemic organ injury and graft dysfunction after transplantation. Thresholds of resuscitation times in brain dead liver donors have not been established so far. We report the case of a brain dead liver donor who experienced 2.5 hours of CPR whose liver was suc-
\end{abstract}


cessfully transplanted. A 75-year-old male experienced CA and was treated by CPR with streptokinase application for 2.5 hours until stabilization of cardiac function. Brain death was diagnosed at the day of admission and organ donation carried out within 24 hours. The DRI was 2.2 with a CIT of 8.8 hours. The liver was transplanted into a 64-year-old recipient suffering from alcoholic liver cirrhosis and a MELD-score of 10 non representative for severity of disease. During follow up of 4 years ERCP and stenting was performed regularly for biliary anastomosis stenosis. The patient remained in a very good overall state of health without any signs of liver dysfunction. This case demonstrates that an extensive period of CPR is not an obligatory exclusion criterion for liver donation. Thresholds of CPR times as well as predictive factors in donors with CA should be established.

Key words: donor risk, liver transplantation, ischemia reperfusion, ischemic preconditioning, extended criteria donor, clinical decision making

\section{Introduction}

Organ shortage remains one of the central limitations in the field of solid organ transplantation and especially liver transplantation (LT) in the last decades. Accordingly, high mortality on the liver transplant waiting lists worldwide persists and new methods to increase the number of organ donors are urgently needed. Nowadays, most organ donors are brain dead donors in the western world (1). Efforts to increase the number of these donors led to the acceptance of livers with advanced risk profiles $(2,3)$, thus, followed by higher incidences of suboptimal graft function after LT, a complication characterized by its high morbidity and mortality $(4,5)$.

The poor outcomes of any patient experiencing cardiac arrest (CA) and cardiopulmonary resuscitation (CPR) demonstrate the extreme negative impact of ischemic injury on the human body and all organ systems $(6,7)$. All organs are in danger of extensive impairment and loss of function in such situations. In organ donors, CA and subsequent CPR might lead to graft dysfunction after transplantation.

We report herein the case of a brain dead liver donor who experienced two and a half hours of cardiopulmonary resuscitation on the day of organ donation, whose liver was nevertheless successfully transplanted.

\section{Case report}

A 64-year-old man suffering from alcoholic liver cirrhosisand relapsing episodes of hepatic encephalopathy with necessity of in-house treatments was listed for liver transplantation at EUROTRANSPLANT in December 2009. Extrahepatic co-morbidities of the patient included coronary artery disease with history of aortocoronary-bypass-surgery, combined aortic valve disease, arterial hypertension, hypercholesterinemia, diabetes mellitus type II, hypothyroidism, bipolar affective disorder and hyperuricemia.

The allocated organ for this patient came from amale donor who experienced cardiac arrest before hospital admission and was treated by cardiopulmonary resuscitation. After arrival of health professionals streptokinase was administered. Accordingly, resuscitation time was prolonged. The complete period of cardiopulmonary resuscitation was documented as hypotensive with subsequent mechanical chest compression and mechanical ventilation. After two and a half hours of treatment a stable cardiac function was achieved and the patient was transported to the hospital and treated in an ICU. Brain death was documented 11.5 hours after hospital admission, and the patient was evaluated for organ donation, which was carried out approximately 24 hours after admission to the ICU. The donated liver had a donor risk index of 2.2. Donor age was 75 years and donor BMI was 25 $\mathrm{kg} / \mathrm{m}^{2}$. Before organ donation the donor was treated with dopamine $(7.5 \mu \mathrm{g} / \mathrm{kg} / \mathrm{min})$ as vasopressor support. Last laboratory values of the donor showed the following results: AST 99 U/1, ALT $142 \mathrm{U} / \mathrm{l}$, Bilirubin $10.8 \mu \mathrm{mol} / \mathrm{l}$, Sodium $146 \mathrm{mmol} / \mathrm{l}$, Creatinine $162 \mu \mathrm{mol} / \mathrm{l}$, lactate $10.3 \mathrm{mmol} / \mathrm{l}$.Organ quality of the liver was described as "acceptable" by the procurement team. The result of a routine biopsy performed during preparation of the cold stored organ indicated $20 \%$ micro- $^{-}$and additional 5\% macrovesicularsteatosis. Cold ischemia time was 8.8 hours. Allocation by EUROTRANSPLANT was carried out as a "rescue offer" (allocated to the first center to accept by multiple-refusal/competitive rescue offer procedure for a rapid allocation and transplantation).

Orthotopic liver transplantation was carried out with cava replacement and end-to-end anastomosis of hepatic artery, portal vein and bile duct. 
Warm ischemia time was 42 minutes. The course of the surgical procedure was complicated by a complex hepatectomy of three hours, due to extensive portal vein collaterals and history of several SBPs. Transfusion of 8 packed red blood units was required. The perioperative immunosuppression regimen consisted of intravenous corticosteroids. Postoperative immunosuppression regimens consisted of a calcineurin-inhibitor (adjusted in accordance to the trough level of the drug) in combination withmycophenolatmofetil and corticosteroids.

Directly post-LT the laboratory results showed peak transaminases as follows: AST $2845 \mathrm{U} / \mathrm{l}$ and ALT 1163 U/l. Spontaneous INR was 2.14 and aPTT 76.3 seconds. Bilirubin showed a value of $4.4 \mathrm{mg} / \mathrm{dl}$ and GT was 19U/1. Routinely performed ultrasound aroused suspicion of hepatic artery thrombosis, so that the patient was taken to the operating room again, where this complication was excluded. In the further course aminotransferases and coagulation parameters were constantly normalizingand the liver showed a good function of synthesis. On the first postoperative day the patient was surgical revised again for suspicion of secondary hemorrhage, which was not confirmed except for a small subhepatic hematoma without acute bleeding signs. Though the patient was primarily cardiopulmonary stable and demonstrated excellent kidney function, he required ICU treatment altogether for 15 days with slightly prolonged air management weaning process, intermittent thoracic drainage and post-operative agitated delirium. With increasing values of bilirubin and enlarged bile ducts in the routine ultrasound an ERCP was performed where a bile duct anastomosis stenosis was diagnosed and treated by dilatation and stent implantation. The patient was transferred to the regular ward on postoperative day 16 , where the further clinical course was uneventful. We discharged the patient after 33 days in a good general state of health, with normal laboratory values and without signs of liver dysfunction.

During the follow up of 4 years ERCP with stent replacement was performed approximately every 12 weeks. The patient remained in a very good overall state of health without any signs of discomfort or liver dysfunction.

\section{Discussion}

The here presented case describes the successful transplantation of a brain dead organ donor liver with history of extensive (meaning two and a half hours) cardiopulmonary resuscitation. In our knowledge this is the longest reported resuscitation time in an organ donor up to date. In our opinion the exceptionally unique clinical observation of this case gives generalizable insights about some aspects of the practice of liver transplantation.

The risk of recent CPR in organ donors has not been intensively analyzed, so far. Indeed, resuscitated patients die not solely because of cardiac failure if they survive the event of cardiac arrest but often of multi-organ failure, resembling that all organs are in danger of extensive ischemic impairment in this situation. The utilization of such donors in liver transplantationhas traditionally been denoted with poor outcomes so that a thorough reasoning before acceptance of such organs is required. Up to date only small studies exist demonstrating possible utilizations of these donors (8-11) despite the risk of ischemic organ injury.

In the presented case the donated organ was afflicted with high risks after transplantation per se what is resembled by the donor risk index of 2.2 (12). Theoretically, the long period of resuscitation with possible suboptimal organ perfusion added up to the risk of this organ. With only scarce data on this subject therelevance of this fact can only be estimated.

So why accept this organ at all for transplantation? The laboratory values after determination of brain death in the donor showed only mild hepatic enzyme leakage and therefore mild hepatocellular injury. This suggested that CPR in the donor was able to achieve sufficient blood flow and oxygenation of the liver tissue, while this was not achieved for the brain leading to brain death. Additionally, biopsy results showed an acceptable steatotic profile and the short time frame from admission to organ procurement was favorable as well. So, beside the downsides of the overall risk assessment by the DRI some preferential facts were in favor of the donated liver, which made us believe that it was acceptable for recipients that have only minimal chances to receive an organ:

The recipient in this case is a patient with relapsing episodes of hepatic encephalopathies and a severity of liver disease that was not reflected by his MELD score correctly. So this patient was in urgent need of transplantation without the prospect of receiving an organ by the standard allocation mechanisms. Acceptance of this particular organ, which was allocated by EUROTRANSPLANT by an alternative allocation mechanism, was one scarce chance for this recipient. The following course after transplantation demonstrates the hazards: beside the appearance of an early allograft dysfunction (13) 
and long ICU treatment with two surgical revisions, biliary difficulties occurred, which are often connected to ischemic organ injury (14). The biliary problem might in part be attributable to the history of CPR with periods of suboptimal blood flow and concomitant ischemic injury. It is of importance that the observed complications were expectedand carefully monitored in the present case, due to the risk profile of the organ, so that an early and optimal treatment was initiated. The long-term follow up of the patient demonstrates the excellent outcome that can be achieved in spite of an extensive donor risk profile by vigilant treatment of all complications. Therefore, such an organ might represent a valuable and relevant chance for selected recipients.

Is it possible to make generalizations out of this case? In fact, in every individual organ the extension of injury should be assessed by all available information (laboratory parameters, clinical factors, radiological diagnostics, biopsies, etc.). This still remains the only way to address all aspects of organ risk assessment and donor-recipient matching. Different systems for organ risk assessments have been developed in the past $(12,15,16)$ and it should be kept in mind that these were developed for overall populations and not for rare scenarios as in the presented case. Of course, an acceptance of every organ donor with history of CPR cannot be recommended. But, nary a donor should be excluded based on the history of CPR either. Further analyses of donor populations are needed to clearly assess the risk of cardiac arrest and resuscitation. Until then, organ donation should be considered as an important endpoint of CPR.

In conclusion, this case demonstrates that an extensive period of cardiopulmonary resuscitation is not an obligatory exclusion criterion for liver donation in brain dead donors, but thoughtful selection of such donors might possibly extend the pool of organ donors.

\section{Conflicts of interest and source of funding: None}

All of the authors have met the criteria for authorship as established by the ICMJE.

\section{References}

1. Adam R, Karam V, Delvart V, O'Grady J, Mirza D, Klempnauer J, et al. Evolution of indications and results of liver transplantation in Europe. A Report from the European Liver Transplant Registry (ELTR). J Hepatol. 2012;57(3):675-88.

2. Sotiropoulos GC, Lang H, Saner FH, Beckebaum S, Wandelt M, Molmenti EP, et al. Long-term results after liver transplantation with "livers that nobody wants" within Eurotransplant: a center's experience. Transpl. Proc. 2008;40(9):3196-7.

3. Radunz S, Paul A, Nowak K, Treckmann JW, Saner FH, Mathé Z. Liver transplantation using donor organs with markedly elevated liver enzymes: how far can we go? Liver Int. 2011;31(7):1021-7.

4. Schaubel DE, Sima CS, Goodrich NP, Feng S, Merion RM. The survival benefit of deceased donor liver transplantation as a function of candidate disease severity and donor quality. Am J Transpl. 2008;8(2):419-25.

5. Merion RM, Goodrich NP, Feng S. How can we define expanded criteria for liver donors? J Hepatol. 2006;45(4):484-8.

6. Mongardon N, Dumas F, Ricome S, Grimaldi D, Hissem T, Pène F, et al. Postcardiac arrest syndrome: from immediate resuscitation to long-term outcome. Ann Intensive Care Springer Open Ltd; 2011;1(1):45.

7. Group TH after CAS. Mild therapeutic hypothermia to improve the neurologic outcome after cardiac arrest. N Engl J Med. 2002; 346(8):549-56.

8. Levesque E, Hoti E, Khalfallah M, Salloum C, Ricca L, Vibert E, et al. Impact of Reversible Cardiac Arrest in the Brain-Dead Organ Donor on the Outcome of Adult Liver Transplantation. Liver Transpl. 2011;17(10):1159-66.

9. Adrie C, Haouache H, Saleh M, Memain N, Laurent I, Thuong M, et al. An underrecognized source of organ donors: patients with brain death after successfully resuscitated cardiac arrest. Intensive Care Med. 2008;34(1):132-7.

10. Schnüriger B, Inaba K, Branco BC, Salim A, Russell K, Lam L, et al. Organ donation: an important outcome after resuscitative thoracotomy. J. Am. Coll. Surg. Elsevier Inc. 2010;211(4):450-5.

11. Faucher A, Savary D, Jund J, Dorez D, Debaty G, Gaillard A, et al. Out-of-hospital traumatic cardiac arrest: an underrecognized source of organ donors. Transpl. Int. 2014;27(1):42-8.

12. Feng S, Goodrich NP, Bragg-Gresham JL, Dykstra DM, Punch JD, DebRoy MA, et al. Characteristics associated with liver graft failure: the concept of a donor risk index. Am J Transpl. 2006;;6(4):783-90.

13. Olthoff KM, Kulik L, Samstein B, Kaminski M, Abecassis M, Emond $\mathrm{J}$, et al. Validation of a Current Definition of Early Allograft Dysfunction in Liver Transplant Recipients and Analysis of Risk Factors. Liver Transpl 2010;16(8):943-9.

14. Seehofer D, Eurich D, Veltzke-Schlieker W, Neuhaus P. Biliary Complications After Liver Transplantation: Old Problems and New Challenges. Am. J. Transplant. 2013; 13(2):253-65.

15. Hoyer DP, Paul A, Gallinat A, Molmenti EP, Reinhardt R, Minor T, et al. Donor Information Based Prediction of Early Allograft Dysfunction and Outcome in Liver Transplantation. Liver Int. 2013; 35(1):156-63.

16. Briceño J, Ciria R, de la Mata M. Donor-recipient matching: Myths and realities. J Hepatol. 2013;58(4):811-20. 